International Business and Global Economy 2018, no. 37, pp. 544-553

Biznes międzynarodowy w gospodarce globalnej 2018, nr 37, s. 544-553

Edited by the Institute of International Business, University of Gdańsk

\title{
The issue of extended free trade area in theory and practice - the case of TTIP
}

\begin{abstract}
A distinctive feature of the integration processes taking place in the modern economy is the growing function of expanded free trade areas (FTA+). The aim of the paper is to characterise their nature and framework, with the starting point being the definition of a free trade area created by Balassa. In this context, the author examines the difference between the traditional definition of a free trade area and the features of FTA +. In doing so, he uses selected TTIP issues that go beyond the classical definition of a free trade area. This also applies to the flow of capital and financial services, as well as the potential impact of TTIP on international payment imbalance.
\end{abstract}

Keywords: FTA+, trade creation effect, trade diversion effect, international payment disequilibrium, TTIP

JEL classification: F36, F37, G20, P33

\section{Problem rozszerzonej strefy wolnego handlu w teorii i praktyce - przypadek TTIP}

Charakterystyczną cechą procesów integracyjnych zachodzących we współczesnej gospodarce światowej jest rosnąca rola rozszerzonych stref wolnego handlu (SWH+). Celem artykułu jest określenie ich istoty i specyfiki, przyjmując jako punkt wyjścia definicję strefy wolnego handlu wywodzącą się od Balassy. W tym kontekście autor rozważa różnicę między tradycyjną definicją strefy wolnego handlu a cechami SWH+. Wykorzystuje w tym celu wybrane zagadnienia TTIP, które wykraczają poza klasyczną definicję strefy wolnego handlu. Dotyczy to również przepływu kapitału oraz usług finansowych, a także potencjalnego wpływu TTIP na międzynarodową nierównowagę płatniczą.

Słowa kluczowe: SWH+, efekt kreacji handlu, efekt przesunięcia handlu, międzynarodowa nierównowaga płatnicza, TTIP

Klasyfikacja JEL: F36, F37, G20, P33 


\section{Introduction}

The modern world economy is shaped by three interwoven processes: globalisation, international economic integration, and market transformation. Although they are seen as three distinct, autonomous socio-economic processes - and as such they are differently defined and presented in the economic literature - they are nevertheless linked by the fact that they are formed by the same driving forces; these forces include technical progress, competitive mechanism, and the institutional factor associated with the actions of the state. Their common goal, both global and national, is gaining economic benefits.

Starting with the general definition of international economic integration as the process of cooperation and joining of national economies towards the goal of gaining economic benefits, we will refer to them as increasing economic efficiency within the integrated national economies and, as a result, within the world economy. On the national level, this is reflected in rising GDP, technical progress, internal and external equilibrium, rising competitiveness and, overall, in an increased welfare.

In this context, it is important to highlight the role of the institutional factor that is, the state - in shaping the integrating connections forged through foreign and international economic policies, which finds its reflection in the objectives and measures of trade policies. The author attempts to assess a relatively new phenomenon in the global economy, which is the emergence of extended free trade zones since the turn of the century. Their assumptions and goals go beyond the framework defined by Balassa for individual forms of integration, expanding in consequence the area of international economics research, part of which is the theory of integration [Budnikowski, 2017].

\section{The nature and framework of an extended free trade area (FTA+)}

Balassa [1961] describes an FTA as an area without customs and quotas but with countries' individual trade policies with respect to other nations. Using this definition, the author attempts to describe the cause and effect in a situation when the scope of a negotiated agreement on a free trade area is broadened beyond the removal of customs and quotas as tools to stimulate mutual trade which, in line with the theory, takes place through trade creation and trade diversion effects [Ładyka, 2000, p. 25].

In practice, extending the scope of a trade agreement within the institutional framework of a free trade area concerns especially services, but also the flow of production factors, particularly capital. Thus, the free trade area as a basic form 
of international economic integration can also be said to "replace" the common market in the field of liberalisation of the flow of production factors, thereby changing the mutual conditions of market access without the need to establish a higher form of integration, i.e., the common market (while bypassing the customs union).

The author does not aspire to define the concept of an extended free trade area $(\mathrm{FTA}+)$ as an identifiable, separate organism with specific properties among traditionally accepted forms of international economic integration following Balassa. However, he provides a notion of it in order to capture phenomena visible in the ongoing integration processes within the free trade area, to assess on that basis the economic benefits derived from FTA+, and then to present implications for international trade and the global economy. Undertaking this issue is justified by many cases already in existence, including ASEAN - AFTA and NAFTA, which are the most representative ones due to their share in global trade and global GDP.

The TTIP case is interesting in this context because it is responsible for the prevailing part of the global trade and global GDP. While it is not clear whether TTIP will be implemented under its current name and negotiated conditions, it is worth considering its assumptions and eventual consequences in the context of the expanded free trade area, bearing in mind the liberalisation of international trade and the increase in the world trade.

\section{TTIP as a case of FTA+}

TTIP, through trade creation and trade diversion effects, will stimulate the EU-US trade and their mutual capital flows, especially direct investments, as well as technology transfer. As a consequence, it will also support the move away from the international payment disequilibrium, the sources of which should be seen in the unbalanced growth of international trade observed since the turn of the century, which led to the emergence of deficit economies and surplus economies. The latter originate in particular from the group of emerging economies pursuing the strategy of open development based on export; this is applicable mainly to the dynamically developing economies of East Asia, especially China.

\subsection{Assumptions and benefits of TTIP}

A free trade area as the form and the base of international economic integration is attractive for a given group of countries because it contributes to an improvement of economic efficiency and standard of living. It is worth noting, 
however, that it is an institutionally organised "second best solution" in relation to the universal freedom of trade [Misala, 2001, p. 351].

As a theoretical concept, a free trade area constitutes the essence of the TTIP. It is the basic form of international economic integration based on establishing preferential conditions for exchange, in this case between the EU and the US, the dominant economies in the global economy, which historically have shaped its development processes [Czarny, 2016]. Given their economic potential (over 50\% share in world GDP and a similar share of their mutual turnover in world trade), it will be the largest free trade area in the global economy. For the US and the EU, this means a change in their trade model resulting in increased mutual trade in goods and services as well as capital, which slowed down following the global financial crisis of $2007 / 8+$.

Although the main reasons for establishing the TTIP lie in the negative consequences of the global financial crisis of $2007 / 8+$ for international trade, in particular for the US and the EU, they must also be seen in the weaknesses of the multilateral liberalisation of international trade within the WTO. For these reasons, which have a global dimension, a conservative model of EU-US trade is imposed that corresponds to the classic GATT/WTO standards with a low share of trade preferences. This is due to the fact that until now the bilateral EU-US trade turnover has been implemented under the Most-Favourable Nation clause (MFN), while the rules governing it (GATT/WTO) do not differ from those that govern trade with third countries. As a consequence, in their mutual trade relations, both the US and the EU apply market protective measures quite freely, especially non-tariff protection tools, thus limiting mutual trade and, as a result, higher forms of cooperation in production and scientific-technical areas. Let us add that the protective measures used also include export support instruments for domestic producers, especially subsidies and preferences in public procurement, which distort the market nature of commercial transactions. A departure from such protectionist practices is also one of the key assumptions of the ongoing TTIP negotiations.

The specific TTIP assumptions, which make it possible to define this agreement as a case of an expanded free trade area, are reflected in the negotiating mandates of its partners. For its part, the European Commission has identified the following areas of negotiation: access to the market of goods and services (tariff barriers, non-tariff barriers - technical standards, phytosanitary standards, rules of origin, anti-dumping procedures); capital flows and investment protection; public orders; protection of intellectual property; small and medium-sized enterprises [EC, 2013].

The US negotiating mandate is described in the USTR Special Report, which, apart from the tasks related to the liberalisation of traditional commodity indus- 
tries, covers issues related to e-commerce, cross-border data flow, labour regulations, transparency of the banking systems, and fight against corruption.

The TTIP project, assuming trade preferences established by the treaty under the extended free trade agreement, significantly changes mutual market access terms. As a result, a new model of EU-US trade will be created, which will bring both direct (contractual) and indirect (spill-over) benefits to the parties of the agreement. The TTIP will also affect foreign trade of third countries and, in that way, affect international trade and the global economy, which will in return impact US-EU trade. The effects of the TTIP will therefore concern the US and the EU (bilateral effect), third countries (external effect), and the global economy (global effect).

Regarding the bilateral benefits, it is worth noting that, following the GATT activities, tariff barriers (mainly customs duties) in US-EU trade are relatively low. Therefore, the margin for their further reduction is relatively small. But, if looked at from the point of view of the commodity structure, including Polish exports, there is room for negotiation. This applies in particular to some agricultural and food products, i.a., tobacco and dairy products (in the case of tobacco the duty rate for Poland is $350 \%$; Polish export of chocolate and food products containing cocoa is discriminated against in a similar manner) [Gurbiel, 2013].

Given the already low duty rates and the relatively low importance of items subject to discrimination, the direct impact of the TTIP on Polish agricultural and food exports will be small, but indirect impact, especially manifested in crowding-out of Polish exports from EU markets, may be significant. Such a threat comes from the fact that the US is the world's largest producer of many agricultural and food products (including beef, poultry, turkey, pork, and wheat) and is already offering them to its European partners on competitive terms. Thus, lowering trade barriers, especially non-tariff barriers (i.e., those that define the specificity of FTA+), may result in an increase in US supplies that displace Polish exports, which may in particular concern poultry meat, eggs, and wheat. The US also expects EU concessions in the area of agri-food production technologies, in particular methods of producing food from genetically modified organisms.

In the above context, it is necessary to emphasise the large asymmetry between the burden of tariff barriers and non-tariff barriers. For example, according to CEPR, chemical products imported to the US are covered by a tariff of $1.2 \%$. Meanwhile, its burden for non-tariff barriers is $19.1 \%$. Europe does not remain passive here. For example, the customs duty on import of passenger cars is $8 \%$ and the burden of non-tariff barriers is $25.5 \%$. According to CEPR, their abolition or significant limitation will be responsible for $80 \%$ of TTIP benefits. 


\subsection{Financial issues as an element of FTA+}

In the case of the TTIP, issues that go beyond the theoretical essence of the free trade area include, i.a., capital flows, especially in the form of direct investments, financial services and the currency issue, as well as the problem of international payment disequilibrium, which places the TTIP among the most important challenges for today's global economy.

It can be assumed that the establishment of new economic mechanisms and institutional solutions in these areas will deepen the convergence of financial markets, in particular banking, insurance, and capital markets, as well as reduce the risk in international financial and commercial transactions, which, in turn, will become a factor stimulating both EU-US trade and the global trade, as well as international capital flows, especially in the form of direct investments.

The EU and US economies play an important role in the global flows of direct investment. However, their share of the global inflow streams is decreasing (in 2014 their share amounted to about $30 \%$, while in 1995 to over 50\%), which is accompanied by the increase in the share of inflow streams from the emerging economies, especially China. The share of the US and the EU in the global outflows of foreign direct investments (FDI) also decreased (from 69\% in 1995 to ca. $46 \%$ in 2014).

An increase in the direct capital flow between the EU and the US, and with that an increase of their share in global flows, involves two TTIP issues: ensuring equal investment conditions for EU countries in the US and reforming the investment protection system, in particular resolution of disputes. In this area, there is a lot of controversy regarding the settlement of disputes between the investor and the state, arising mainly due to changes in legal regulations (ISDS, Investor-State Dispute Settlement). According to the negotiation assumptions, the TTIP is to replace the existing national systems used by EU member states when dealing with the US (Poland concluded the ISDS agreement with the US in 1990). Its goal in this area will be a mutual protection of European and American investors and ensuring permanent rules in EU-US trade, which will also contribute to further growth of capital trading.

The development of financial services will play an important role in stimulating not only commercial, but also capital flows between the EU and the US. In the TTIP project, financial services have not been separately defined. Instead, they were listed and grouped on the basis of the subject criteria and the specificity of activities related to them. These included, i.a.: banking and insurance services; transfers of debt securities deposits; services related to the collection and processing of data; management of investment banks, hedge funds, private equity funds, and their deposits [Żukrowska, 2014]. 
The strategic importance of financial services in the TTIP project is reflected by their significant share in the global export and import of both countries and their mutual trade. In 2013, at the starting point of negotiations, exports of financial services by the EU amounted to approximately EUR $60 \mathrm{bn}$, while imports to about $23 \mathrm{bn}$. In the case of the US, exports of financial services (excluding insurance) amounted to $84 \mathrm{bn}$, while imports to $18 \mathrm{bn}$. The EU accounted for $38 \%$ of these exports, and $48 \%$ of imports. The real benefits resulting from the liberalisation and modernisation of financial services will also be affected by the possible regulations regarding EUR-USD.

The currency issue, whose essence is the exchange rate policy and monetary policy, is not covered by the TTIP project, which may mean that both parties are in the position of conducting an autonomous monetary and monetary policy. It can also be assumed that such a position may come from the integration theory itself, according to which the essence of a free trade area is to abolish trade barriers, i.e., tariff and non-tariff restrictions, in mutual economic relations, while maintaining autonomous trade policy with third countries and autonomy in financial matters and technology transfer. Let us emphasise that, in line with the integration theory and solutions adopted in the global economy, the exchange rate and monetary policy issues refer to the economic and monetary union - i.e., a higher form of international economic integration, combining elements of a common market and a single currency, an example of which is the euro area. Although not included in the negotiations, the currency issue is present in the academic and expert debate on issues indirectly related to the TTIP.

The above situation raises a question, by no means rhetorical, should the TTIP project, in its final form, include a reference to an exchange rate and monetary policy? The official approach of both the US and the EU is passive, but this does not mean that following expert and academic debate the final version of the TTIP will not include a record on the currency issue.

Against this background, the Polish proposal to include a currency issue in the TTIP project, which suggest that TTIP negotiators should consider supplementing the agreement with elements of an exchange rate and monetary policy, referring to the bilateral EU-US trade relations, is interesting. The proposal includes a suggestion to strengthen the ECB-Fed cooperation (for example in the form of a permanent committee for monitoring US and EU monetary policy), and a suggestion to consider coordination in the area of USD-EUR exchange management, in particular establishing appropriate bandwidth fluctuations. Establishing a transatlantic financial institute with an advisory function to the ECB and the Fed is also suggested [Dunin-Wąsowicz, 2015].

Although the chances of introducing the Polish proposal to the already negotiated scope of the TTIP are small, it is worth continuing the effort to have them in- 
cluded, as it would facilitate linking trade and financial issues in EU-US bilateral relations, as well as provide a tool for overcoming international payment disequilibrium.

\section{TTIP and third countries from the perspective of international payment imbalance}

According to the European Commission, the TTIP can contribute to an annual trade growth with third countries by EUR 33 bn (as a result of increased bilateral trade and service turnover and trade with third countries, an increase in EU exports by $6 \%$ and the US by $8 \%$ can be expected, which translates to additional EUR $220 \mathrm{bn}$, and this, in connection to $240 \mathrm{bn}$ of revenue for European and American exporters respectively, due to bilateral trade, may, according to CEPR, mean an increase in global trade by 460 bn on an annual basis).

Will there really be an increase in trade with third countries following the TTIP? This question, crucial from the point of view of the future of international trade, and thus the subjective changes of the world economy, appears fundamental for the analysis of the effects of the TTIP. It should be emphasised that doubts occur especially when the trade diversion effect proves stronger than expected, i.e., leads to a relative decline in trade with third countries - and this is highly probable, especially with regard to surplus emerging economies whose exports to the EU and US markets may be reduced as a result of the TTIP.

The impact of the TTIP on third countries will depend on the effects of lowering the tariff and non-tariff barriers and increasing EU-US trade. While an almost complete elimination of tariff barriers can be considered in the medium term, full elimination of non-tariff barriers is likely to go beyond this time horizon. Therefore, the actual negative impact of the TTIP on third countries related to the trade diversion effect may be small in the medium term. However, this does not change the fact that the TTIP, as a potential permanent agreement, may in the long run significantly limit exports of third countries, including surplus emerging economies, in particular China. As a consequence, the TTIP may also affect the reduction of international payment disequilibrium; this, however, will depend on the degree of consideration of financial issues in the agreement, which will determine the specifics of the TTIP as an expanded free trade area in relation to the problem of deficit and surplus economies. This is due to the fact that the phenomenon of dynamic growth of the economies of East Asia is accompanied by a relatively slower activity of highly developed economies, especially the US and Western Europe, and the growing current account deficits as a result of their greater imports from than exports to the East Asian countries. This situation, deepening 
since the turn of the century, leads to the collapse of the international payment equilibrium, becoming one of the most important causes of the global financial crisis [Starzyk, 2017].

A return to international payment equilibrium is, therefore, associated with the increase in the competitiveness of highly developed economies, especially the US and Western Europe. An important role in this process may be played by the TTIP as an extended free trade area, which in this case is also characterised by a reduction of tariff and non-tariff barriers, liberalization of capital flows, especially in the form of direct investments, as well as technology.

\section{Conclusions}

The TTIP is one of many initiatives in the field of free trade areas. However, compared to the previous attempts, it is the most important as it concerns countries that shape the directions of development of international trade and the global economy.

Even if the TTIP will be replaced by another agreement, it can serve as an example of a theoretical model of an extended free trade area, where tariff and nontariff restrictions are reduced, production factors, especially capital, are liberalized, and new financial mechanisms and institutions coordinating mutual financial and economic relations are established.

merging economies, and, as a result, a decline in their position in international trade. This applies especially to China. This way, the TTIP will be able to influence the reduction of current international payment disequilibrium and improve the position of the EU and the US in the area of international trade and the global economy. This is one of the scenarios worth considering when analysing the current challenges of the global economy.

TTIP assumptions, diverging from the classical concept of a free trade area, are a good example for theoretical considerations on the aspects of FTA+ and future forms of international economic integration. Practically speaking, the TTIP experience can also be useful in the event of disintegration, for example if Britain's exit from the EU takes the form of an expanded free trade area.

\section{References}

Balassa B., 1961, The Theory of Economic Integration, George Allen and Unwin, London. Budnikowski A., 2017, Ekonomia międzynarodowa, Polskie Wydawnictwo Ekonomiczne, Warszawa.

Czarny E., 2016, Partnerstwo transatlantyckie. Wnioski dla Polski, Polskie Wydawnictwo Ekonomiczne, Warszawa. 
Dunin-Wąsowicz M., 2015, Kwestia walutowa a TTIP w perspektywie międzynarodowej ekonomii politycznej, [in:] Transatlantyckie partnerstwo w dziedzinie handlu i inwestycji. Nowy etap instytucjonalizacji wspótpracy UE-USA, eds. M. Dunin-Wąsowicz, A. Jarczewska, Wydawnictwo Naukowe Scholar, Warszawa.

EC, 2013, European Commission, Transatlantic Trade and Investment Partnership: The Regulatory Part, http://trade.ec.europa.eu/doclib/docs/2013/july/tradoc_151605.pdf [access: 06.08.2018].

Gurbiel R. (ed.), 2013, Szanse i wyzwania dla biznesu, Raport Amerykańskiej Izby Handlowej w Polsce, Warszawa.

Ładyka S., 2000, Z teorii integracji gospodarczej, Katedra Integracji Europejskiej im. J. Monneta, Kolegium Gospodarki Światowej SGH, Warszawa.

Misala J., 2001, Wspótczesne teorie wymiany międzynarodowej i zagranicznej polityki ekonomicznej, Szkoła Główna Handlowa, Warszawa.

Starzyk K., 2017, Problem międzynarodowej nierównowagi płatniczej w świetle strategii rozwoju otwartego gospodarek wschodzacych, [in:] Handel zagraniczny i biznes międzynarodowy we wspótczesnej gospodarce, eds. M. Maciejewski, K. Wach, UE w Krakowie, Kraków.

Żukrowska K., 2015, Ustugi finansowe w umowie TTIP, [in:] Transatlantyckie partnerstwo $w$ dziedzinie handlu i inwestycji, eds. M. Dunin-Wąsowicz, A. Jarczewska, Wydawnictwo Naukowe Scholar, Warszawa.

K. Starzyk (酒) starzyk.k@gmail.com

Wyższa Szkoła Bankowa w Poznaniu, ul. Zdrojowa 77, 02-927 Warszawa, Polska 